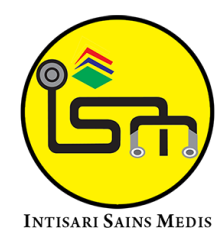

Published by Intisari Sains Medis

\section{Glaucoma drainage devices implantation in uveitic glaucoma: a systematic review}

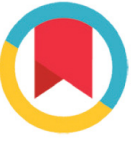

CrossMark

\author{
Ardelia Emily ${ }^{1 *}$, Novanita Shirley Satolom², Franky Richard Kasih², \\ Kevin ${ }^{3}$, Bobby Kristianto ${ }^{4}$
}

'Faculty of Medicine, Universitas Kristen Maranatha, Bandung, Indonesia

${ }^{2}$ Department of Ophthalmology, Universitas Sam Ratulangi, Prof. Dr. dr. Kandou General Hospital, Manado, Indonesia

${ }^{3}$ Department of Ophthalmology, KMN Eye Care, Jakarta, Indonesia

${ }^{4}$ Department of Ophthalmology, dr. Rubini Regional Hospital, Mempawah, West Kalimantan, Indonesia

*Corresponding to: Ardelia Emily; Faculty of Medicine, Universitas Kristen Maranatha, Bandung, Indonesia; ardeliaemily@gmail.com

Received: 2021-06-12

Accepted: 2021-08-15

Published: 2021-08-31

\title{
ABSTRACT
}

Background: Uveitis is broadly defined as inflammation of the uvea. Glaucoma is the third most common complication of uveitis. Uveitic Glaucoma (UG) is known to be refractory, and multiple surgeries are often required for proper treatment. The purpose of this study is to determine the effectiveness of Glaucoma Drainage Device (GDD) implantation as a surgical procedure in UG patients.

Method: We conducted a systematic search of electronic databases from PubMed, Science Direct, and SpringerLink using a combination of relevant keywords was performed by 5 independent reviewers. Various search terms, including 'glaucoma drainage device', 'glaucoma drainage implants', 'glaucoma filtration implants,' 'aqueous shunts', 'uveitic glaucoma',

'inflammatory glaucoma'.

Result: A total of 143 articles were retrieved, but only 14 articles were eligible for data extraction. There are 631 eyes from 583 patients who had UG, 442 eyes underwent GDD implantation. Overall, intraocular pressure and the use of glaucoma medication were reduced. Mean IOP preoperative is $31.57 \mathrm{mmHg}$, and IOP postoperative is $14.48 \mathrm{mmHg}$. There is a reduction in IOP of an average of $17.09 \mathrm{mmHg}$. The number of glaucoma medications has decreased from 3.24 to 1.29 postoperatively.

Conclusion: UG has been shown to be managed successfully by GDD implantation. GDD implantation may be considered a long-term effective surgical option for patients with UG.

Keywords: glaucoma drainage device, refractory glaucoma, uveitic glaucoma

Cite This Article: Emily, A., Satolom, N.S., Kasih, F.R., Kevin., Kristianto, B. 2021. Glaucoma drainage devices implantation in uveitic glaucoma: a systematic review. Intisari Sains Medis 12(2): 672-679. D0I: 10.15562/ism. v12i2.1087

\section{INTRODUCTION}

Uveitis is broadly defined as inflammation of the uvea. The uvea consists of the middle, pigmented, vascular layer of the eye and includes the iris, ciliary body, and choroid. The etiology of uveitis is infectious or inflammatory and is variably associated with systemic disease. ${ }^{1}$

Uveitis is responsible for approximately $10 \%$ of all blindness in the United States and Europe and up to $25 \%$ of blindness worldwide. Uveitis incidence peaks between 20 and 60 years of age. Recent data suggests that it may also increase over the age of 65 . Women have slightly higher rates of uveitis overall. Prevalence is about five to tenfold lower in children than in adults. Anterior uveitis is the most common type of uveitis, representing $70-80 \%$ of cases, followed by pan uveitis, posterior uveitis, and intermediate uveitis ${ }^{1}$ Glaucoma is the third most common complication of uveitis after cystoid macular edema and cataract, and it is seen in $10-20 \%$ of patients with uveitis develop. ${ }^{2,3}$ Considerably higher rates of glaucoma (30-50\%) have been described in eyes with specific uveitic syndromes, including juvenile-rheumatoidarthritis-associated iridocyclitis, Fuchs' heterochromic iridocyclitis, Lymeassociated uveitis, and cancer-associated uveitis. $^{4}$

The intraocular pressure is usually below normal in uveitis because the inflamed ciliary body is functioning poorly. ${ }^{5}$ The underlying mechanism of uveitic glaucoma (UG) has not been fully understood. ${ }^{2}$ However, the elevation of intraocular pressure may also occur through a number of different mechanisms. $^{5}$ Etiology of uveitis, inflammatory mechanism, and steroid treatment have impacts on glaucoma development. ${ }^{2}$

UG is known to be refractory, and multiple surgeries are often required for proper treatment. ${ }^{6}$ Medical management of UG requires aggressive control of both intraocular inflammation and IOP, as well as prevention of glaucomatous optic nerve damage and visual field loss. ${ }^{1}$ Surgical intervention may be indicated if intraocular pressure (IOP) cannot be adequately controlled by medication alone. $^{3}$

Trabeculectomy is the most widely performed surgical procedure in refractory glaucomas, but its long-term success rate is limited in UG. ${ }^{2}$ Prior literature suggests 
that trabeculectomy has good outcomes in UG in the short term, the risk of failure is relatively high in the long term. ${ }^{3}$ The major complication of this procedure is bleb fibrosis. Although the application of antifibrotic agents such as mitomycin $\mathrm{C}$ has been used in surgery, the success rate of filtration surgery remains unsatisfactory. ${ }^{7}$

In recent years, aqueous drainage devices have been widely used to treat uveitic glaucoma. ${ }^{7}$ Glaucoma drainage implants have been shown to be effective for long-term success in uveitic glaucoma. ${ }^{8}$ The purpose of this study is to determine the effectiveness of GDD implantation as a surgical procedure in uveitic glaucoma patients.

\section{METHOD}

\section{Literature Research}

We conducted a systematic review on the effectiveness of glaucoma drainage device implantation for uveitic glaucoma patients. This study was performed following the Preferred Reporting Items for Systematic Reviews and Meta-Analyses (PRISMA) guidelines. A systematic search of electronic databases from PubMed, Science Direct and SpringerLink using a combination of relevant keywords was performed by 5 independent reviewers. Various search terms, including glaucoma drainage device, glaucoma drainage implants, glaucoma filtration implants, aqueous shunts, uveitic glaucoma, inflammatory glaucoma.

To formulate eligibility criteria, we used the SPIDER model for clinical questions (sample, phenomenon of interest, design, evaluation, and research type). SPIDER tool allows researchers to focus on a specific question and determine specific exclusion and inclusion criteria that are used when selecting studies to be included in the systematic review.

\section{Inclusion Criteria}

1. From any country

2. Studies in the human eye

3. Published from 10 years ago to the present day

4. Published in English

5. Appropriate study design: clinical trials, case report, case series, RCT, retrospective, prospective study, comparative study, observational study.

\section{Exclusion Criteria}

1. Non-research: editorials, letters, methodology papers, editorial and narrative review articles

2. Research: systematic review, metaanalysis

3. Non-English article/publication

4. Subject(s) had other ocular or nonocular conditions

5. Flawed study design

\section{Data Analysis}

From the retrieved studies, titles and abstracts were scanned, then the fulltext was read, and the reference lists from all identified studies were scanned in the same way to find other eligible studies. We descriptively analyzed all data included in this study. We recorded intraocular pressure (IOP), visual acuity (VA), inflammation, number of glaucoma medications, and number of antiinflammatory medications preoperative and postoperative.

\section{RESULT}

A total of 143 articles were retrieved by searching the previously mentioned databases. After screening, there were 14 articles eligible for data extraction. The PRISMA flow diagram demonstrating the selection process is displayed in Figure $\mathbf{1 .}$

\section{Table 1. SPIDER Tool}

\begin{tabular}{ll}
\hline Sample & Patient with uveitic glaucoma \\
Phenomenon of Interest & Effectiveness of GDD implantation for uveitic glaucoma \\
Design & Systematic review \\
Evaluation & Outcome after GDD implantation \\
Research Type & Qualitative method \\
\hline
\end{tabular}
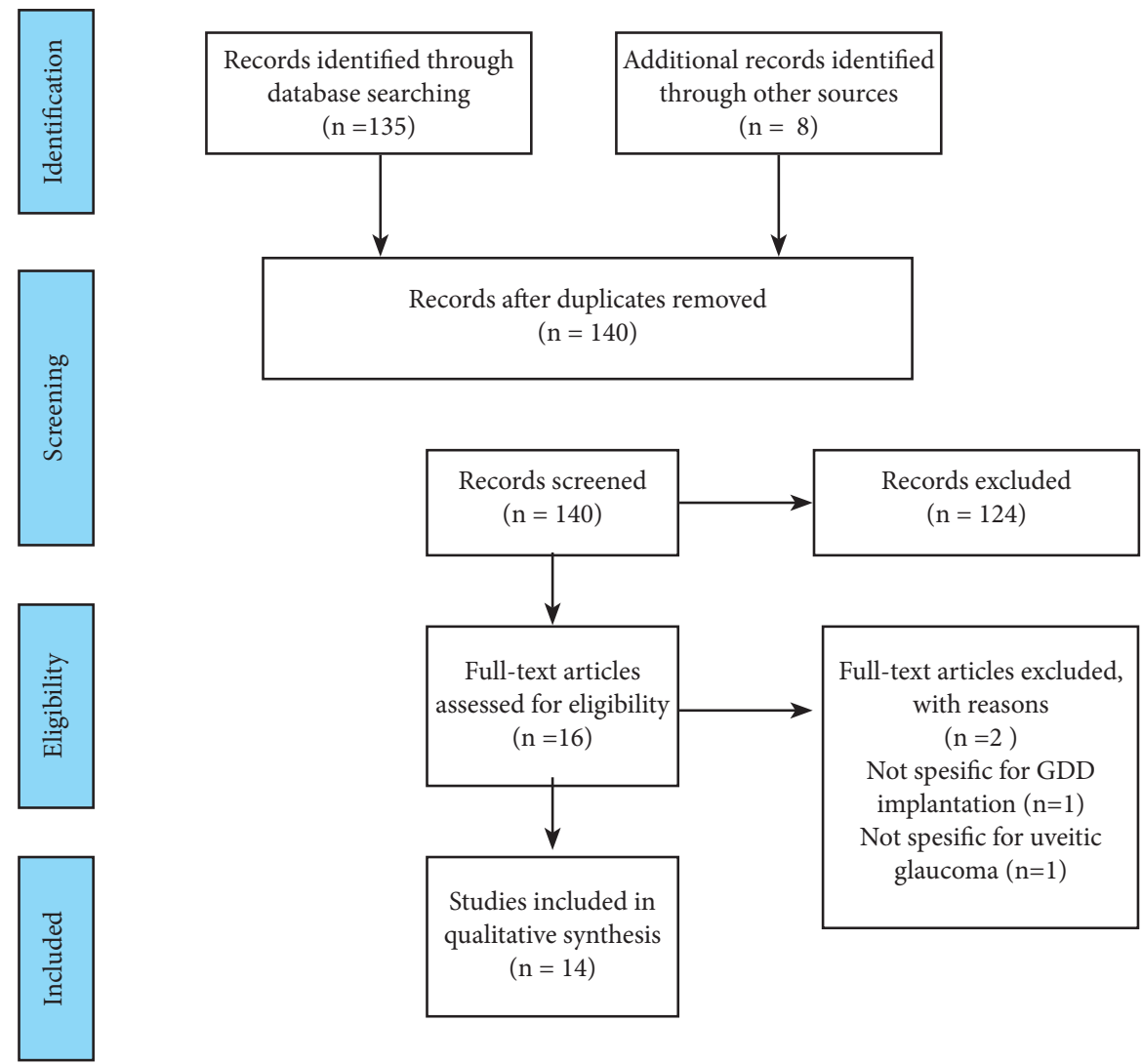
qualitative synthesis $(\mathrm{n}=14)$

Figure 1. PRISMA Flow Diagram 
A total of 631 eyes from 583 patients had uveitic glaucoma, 442 eyes underwent glaucoma drainage device implantation. Follow-up duration was varied between 6 months to five years. Of the 14 studies, 5 studies compared GDD implantation to trabeculectomy, 3 studies compared GDD implantation to a combination of GDD and fluocinolone implantation, 1 study compared GDD implantation to goniotomy, and 5 studies reported the outcome of GDD implantation for uveitic glaucoma patients. In this study, we focused on efficacy and outcome GDD implantation for treated uveitic glaucoma.

Table 1 demonstrates the demographic characteristics of included studies. Studies were conducted in 12 different countries. There was variation in the type of GDD, valve and non-valve implant. The study population included adult and pediatric uveitic glaucoma patients. All articles were published between 2013 and 2020 . In this study, we determined the efficacy and outcome of GDD implantation due to comparison in intraocular pressure (IOP), visual acuity (VA), inflammation, number of glaucoma medication, and number of anti-inflammatory medication preoperative and postoperative.

We summarize our research data in Table 2. Overall, IOP was reduced as the effect of GDD implantation, as seen in Figure 2. Mean IOP preoperative is 31.57 $\mathrm{mmHg}$, and IOP postoperative is 14.48 mmHg. There is a reduction in IOP of an average of $17.09 \mathrm{mmHg}$. Not all studies record changes in VA. Most of the studies show there was no significant improved VA postoperatively.

Bohnsack et al. quantified inflammation uniformly by the number of cells per highpower field; at the final examination, one eye showed no inflammation postoperatively, but the rest of the eyes remained the same. ${ }^{9}$ Sevgi et al. found the presence of inflammation did not change significantly in the Ahmad Glaucoma Valve (AGV), the only group compared to the AGV+ fluocinolone implant group. ${ }^{10}$ In line with Sevgi et al., Zivney et al. found fluocinolone implant had better control intraocular inflammation. ${ }^{10,11}$

Figure 3 showed the number of glaucoma medications was decreased postoperatively in all studies on average

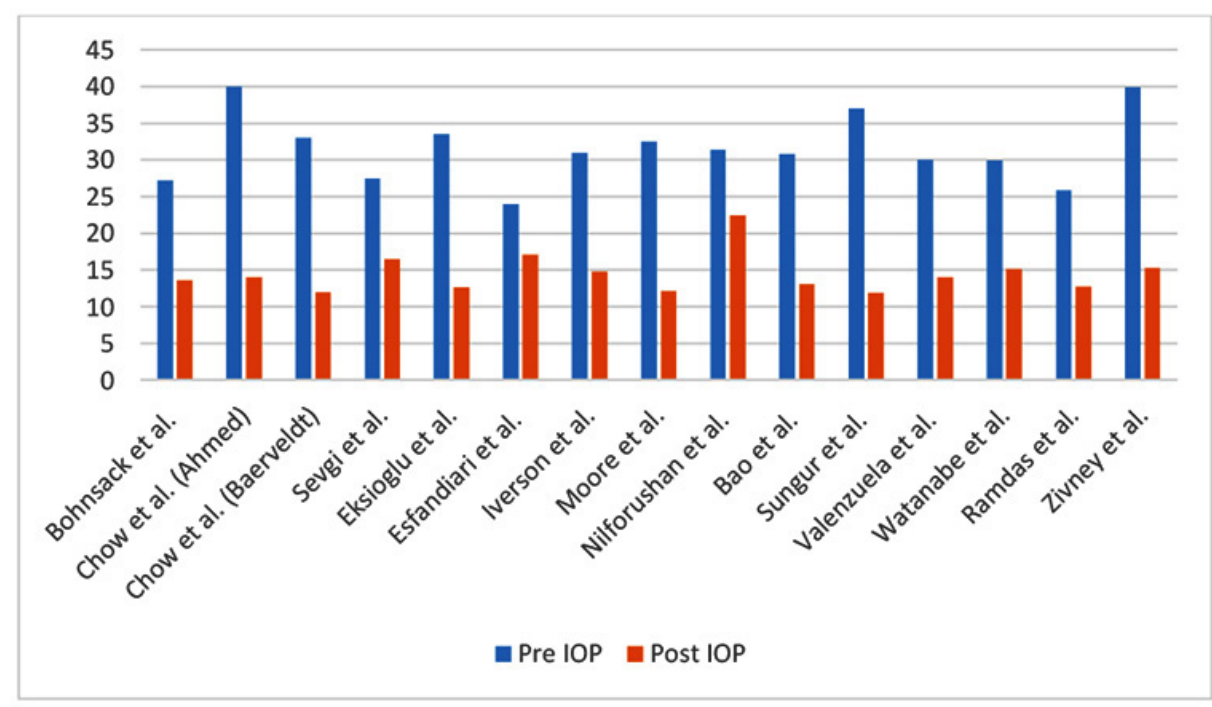

Figure 2. Preoperative and Postoperative IOP

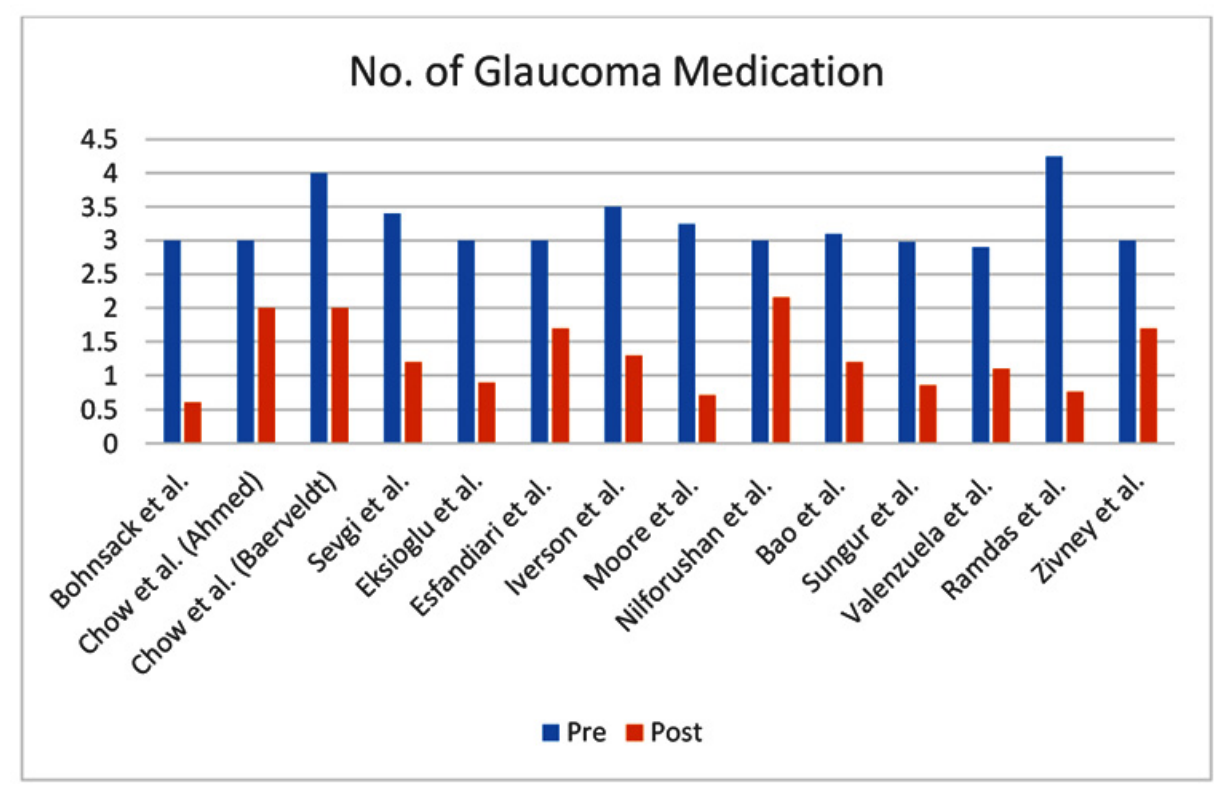

Figure 3. Preoperative and postoperative number of glaucoma medication

decrease from 3.24 to 1.29 . Bohnsack et al. and Chow et al. found that there was no difference in anti-inflammatory medication use before and after surgery.,9

Generally, common complications were hypotony, choroidal effusion, hyphema, shallow anterior chamber, blocked tube, and corneal edema.

\section{DISCUSSION}

Uveitis is a common cause of blindness and is characterized by recurrent intraocular inflammation of the eyes. One of the major complications is glaucoma. ${ }^{7}$ Patients with both glaucoma and uveitis have a higher risk of severe visual impairment. ${ }^{12}$ Elevation of intraocular pressure may occur through a number of different mechanisms. The trabecular meshwork may become blocked by inflammatory cells (trabeculitis). One of the most causes of raised intraocular pressure in individuals with uveitis is the use of topical steroids. Chronic or 
Table 2. Demographic characteristic of included study

\begin{tabular}{|c|c|c|c|c|c|c|c|c|c|}
\hline No. & Author (Year) & Location & Study Design & $\begin{array}{l}\text { Sample } \\
\text { Size }\end{array}$ & Eyes & Male & Female & Population & Follow Up \\
\hline 1 & $\begin{array}{l}\text { Bohnsack et } \\
\text { al. (2013) }\end{array}$ & Chicago & $\begin{array}{l}\text { Retrospective } \\
\text { case series }\end{array}$ & 36 & 36 & 13 & 23 & $\begin{array}{l}\text { Pediatric uveitic } \\
\text { glaucoma patients } \\
\text { (mean age } 11.1 \pm 4.4 \\
\text { years old) }\end{array}$ & $5.6 \pm 4.8$ years \\
\hline 2 & $\begin{array}{l}\text { Chow et al. } \\
(2018)\end{array}$ & California & $\begin{array}{l}\text { Retrospective } \\
\text { comparative } \\
\text { study }\end{array}$ & 147 & 147 & 64 & 83 & $\begin{array}{l}\text { Uveitic glaucoma } \\
\text { patients (19-96 years } \\
\text { old) }\end{array}$ & 1 year \\
\hline 3 & $\begin{array}{l}\text { Sevgi et al. } \\
\text { (2017) }\end{array}$ & Massachusetts & $\begin{array}{l}\text { Retrospective } \\
\text { comparative } \\
\text { study }\end{array}$ & 13 & 18 & 7 & 6 & $\begin{array}{l}\text { Uveitic glaucoma } \\
\text { patients (mean age } \\
56.5 \text { years old) }\end{array}$ & 1 year \\
\hline 4 & $\begin{array}{l}\text { Eksioglu et } \\
\text { al. (2017) }\end{array}$ & Turkey & $\begin{array}{l}\text { Retrospective } \\
\text { case series }\end{array}$ & 11 & 16 & 8 & 3 & $\begin{array}{l}\text { Pediatric uveitic } \\
\text { glaucoma patients } \\
\text { (mean age } 14 \text { years } \\
\text { old) }\end{array}$ & $\begin{array}{l}64.46 \pm 33.56 \\
\text { months }\end{array}$ \\
\hline 5 & $\begin{array}{l}\text { Esfandiari et } \\
\text { al. (2018) }\end{array}$ & Tehran & $\begin{array}{l}\text { Retrospective } \\
\text { comparative } \\
\text { study }\end{array}$ & 26 & 26 & 14 & 12 & $\begin{array}{l}\text { Uveitic glaucoma } \\
\text { patients (mean age } \\
46.6 \text { years old) }\end{array}$ & $\begin{array}{l}33.7 \pm 17.8 \\
\text { months }\end{array}$ \\
\hline 6 & $\begin{array}{l}\text { Iverson et al. } \\
(2015)\end{array}$ & Miami & $\begin{array}{l}\text { Retrospective } \\
\text { comparative } \\
\text { study }\end{array}$ & 42 & 42 & 15 & 27 & $\begin{array}{l}\text { Uveitic glaucoma } \\
\text { patients (mean age } \\
62.5 \text { years old) }\end{array}$ & 5 years \\
\hline 7 & $\begin{array}{l}\text { Moore et al. } \\
(2015)\end{array}$ & Durham & $\begin{array}{l}\text { Retrospective } \\
\text { interventional } \\
\text { study }\end{array}$ & 60 & 62 & 29 & 31 & $\begin{array}{l}\text { Uveitic glaucoma } \\
\text { patients (mean age } \\
47.5 \text { years old) }\end{array}$ & 2 years \\
\hline 8 & $\begin{array}{l}\text { Nilforushan } \\
\text { et al. (2018) }\end{array}$ & Tehran & $\begin{array}{l}\text { Retrospective } \\
\text { cohort study }\end{array}$ & 28 & 28 & 15 & 13 & $\begin{array}{l}\text { Patients with Fuchs } \\
\text { uveitis syndrome } \\
\text { (mean age } 44.5 \text { years } \\
\text { old) }\end{array}$ & $\begin{array}{l}23.06 \pm 12.03 \\
\text { months }\end{array}$ \\
\hline 9 & $\begin{array}{l}\text { Bao et al. } \\
(2018)\end{array}$ & China & $\begin{array}{l}\text { Retrospective } \\
\text { non- } \\
\text { comparative } \\
\text { study }\end{array}$ & 56 & 67 & 29 & 27 & $\begin{array}{l}\text { Uveitic glaucoma } \\
\text { patients ( } 24-65 \text { years } \\
\text { old) }\end{array}$ & $\begin{array}{l}53.3 \pm 8.5 \\
\text { months }\end{array}$ \\
\hline 10 & $\begin{array}{l}\text { Sungur et al. } \\
\text { (2017) }\end{array}$ & Turkey & $\begin{array}{l}\text { Retrospective } \\
\text { study }\end{array}$ & 39 & 46 & 17 & 22 & $\begin{array}{l}\text { Uveitic glaucoma } \\
\text { patients (19-66 years } \\
\text { old) }\end{array}$ & $\begin{array}{l}51.93 \pm 23.08 \\
\text { months }\end{array}$ \\
\hline 11 & $\begin{array}{l}\text { Valenzuela et } \\
\text { al. (2018) }\end{array}$ & Spain & $\begin{array}{l}\text { Retrospective } \\
\text { case series }\end{array}$ & 21 & 26 & 11 & 10 & $\begin{array}{l}\text { Uveitic glaucoma } \\
\text { patients (13-75 years } \\
\text { old) }\end{array}$ & $\begin{array}{l}53.5 \pm 31 \\
\text { months }\end{array}$ \\
\hline 12 & $\begin{array}{l}\text { Watanabe et } \\
\text { al. (2020) }\end{array}$ & Tokyo & $\begin{array}{l}\text { Retrospective } \\
\text { study }\end{array}$ & 41 & 45 & 24 & 17 & $\begin{array}{l}\text { Uveitic glaucoma } \\
\text { patients }\end{array}$ & $\begin{array}{l}50.9 \pm 33.68 \\
\text { months }\end{array}$ \\
\hline 13 & $\begin{array}{l}\text { Ramdas et al. } \\
(2018)\end{array}$ & Rotterdam & $\begin{array}{l}\text { Retrospective } \\
\text { case-control } \\
\text { study }\end{array}$ & 38 & 38 & 14 & 24 & $\begin{array}{l}\text { Uveitic glaucoma } \\
\text { patients (mean age } \\
44.4 \text { years old) }\end{array}$ & 1 year \\
\hline 14 & $\begin{array}{l}\text { Zivney } \\
(2016)\end{array}$ & Portland & $\begin{array}{l}\text { Retrospective } \\
\text { comparative } \\
\text { study }\end{array}$ & 25 & 34 & 6 & 19 & $\begin{array}{l}\text { Uveitic glaucoma } \\
\text { patients (mean age } \\
50 \text { years old) }\end{array}$ & 6 months \\
\hline
\end{tabular}




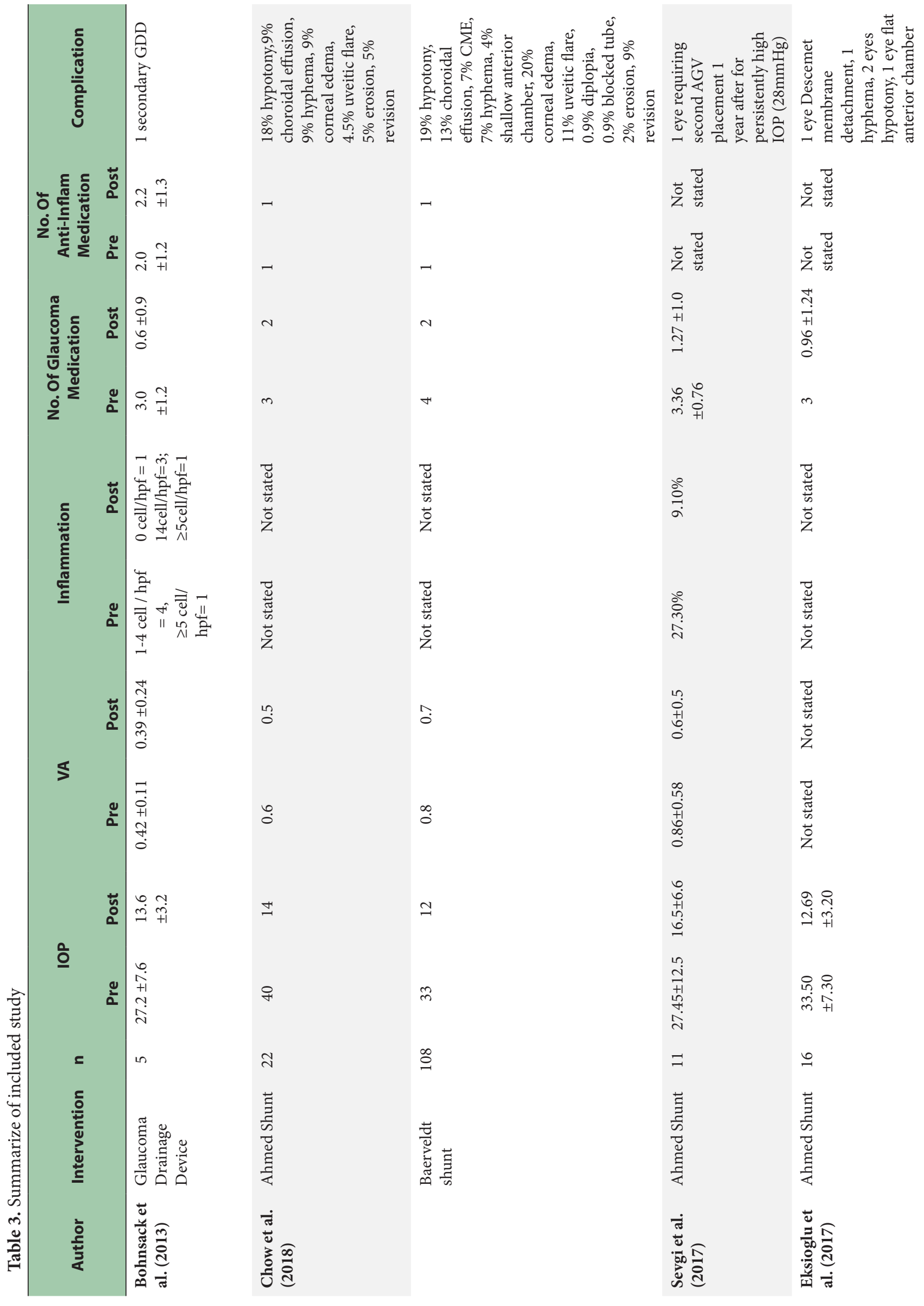




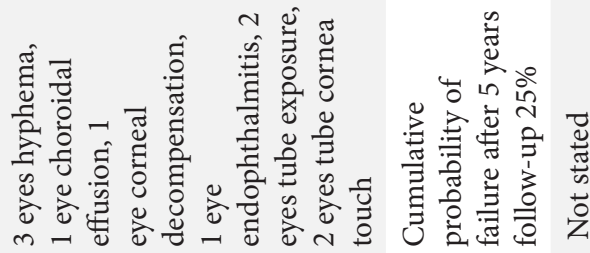

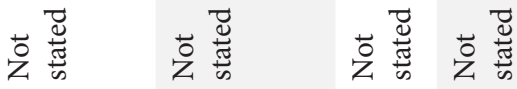

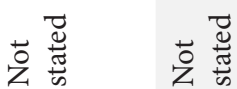

蓄 동

路辛总

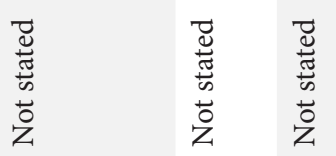

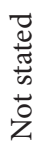

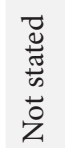

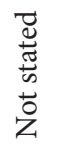

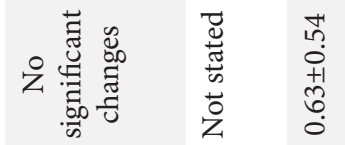

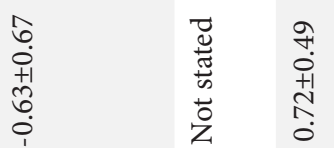

$\dddot{n} \quad \cdots$

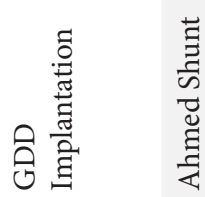

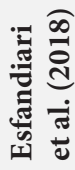

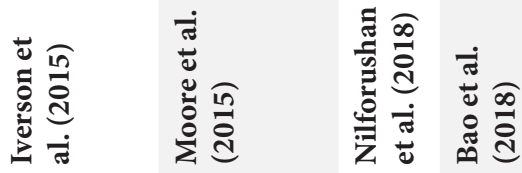

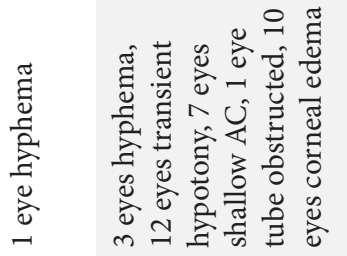

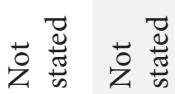

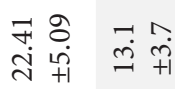

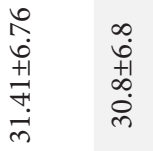

$\simeq \hat{\circ}$
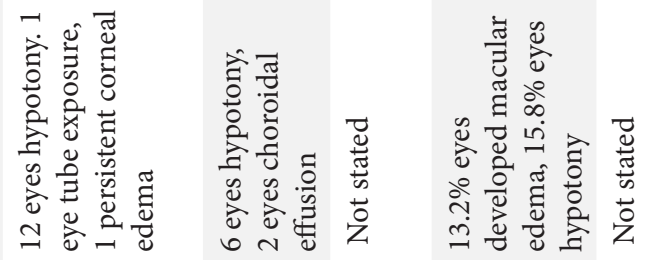

总蓄

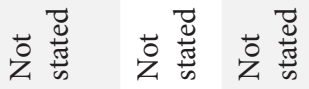

芸蒙

芸咅

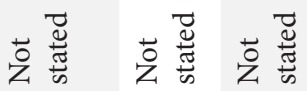

芸旁

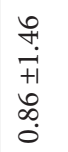

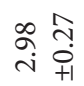

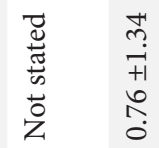

ब

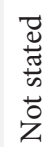

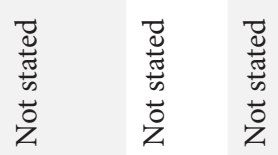

$\stackrel{\circ}{3}$

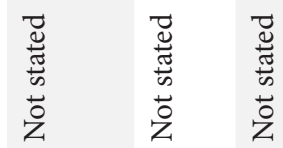

ڤें

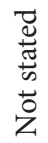

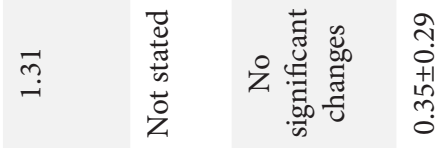

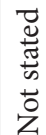

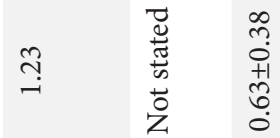

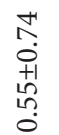

$\stackrel{\infty}{=} \stackrel{\substack{n \\+1}}{+1}$

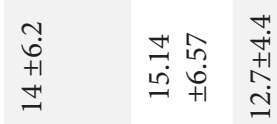

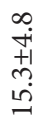

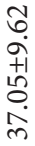

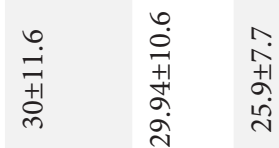

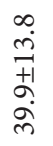

\&

i

$\vec{\sim} \quad \infty$

章

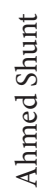

竞

กิ 仓ิ

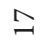

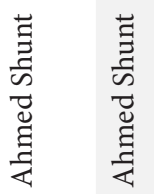

竎令 客

암

西 
recurrent uveitis produces permanent impairment of trabecular function, peripheral anterior synechiae, and occasionally angle neovascularization, all of which increase the chance of secondary glaucoma. Seclusio puppilae due to $360^{\circ}$ posterior synechiae produces iris bombe and acute angle-closure glaucoma. ${ }^{5}$

It is one of the most difficult forms of glaucoma to manage because the ophthalmologist must simultaneously address inflammation and elevated IOP as well as prevention of glaucomatous optic nerve damage and visual field loss. ${ }^{1,12}$ Treatment is directed chiefly at controlling the uveitis with concomitant medical glaucoma therapy as necessary. ${ }^{5}$

There are many therapies used to treat uveitic glaucoma. ${ }^{7}$ Aqueous suppressants are generally the first-line agents. Prostaglandin analogs may be used to treat uveitic glaucoma and generally do not exacerbate intraocular inflammation, especially when used concomitantly with immunomodulatory therapy (IMT) and corticosteroids. ${ }^{1}$ The choice of additional agents often depends on the IOP level. If this is very high, oral acetazolamide may be required. For moderate elevation (e.g. less than $35 \mathrm{mmHg}$ on a beta-blocker) in the absence of significant glaucomatous damage, an alpha-adrenergic agonist or topical carbonic anhydrase inhibitor (CAI) might be adequate. ${ }^{13}$ Use of pilocarpine (miotic) should be avoided in uveitis, as the smaller fixed pupil may be at risk for worsening of posterior synechiae, and pilocarpine causes a breakdown of the blood-aqueous barrier. ${ }^{1}$

When medical management fails, glaucoma filtering surgery is indicated. ${ }^{1}$ Among the current surgical treatment options are trabeculectomy, deep sclerectomy, minimally invasive glaucoma surgery (MIGS), cyclodestructive procedures, and several types of glaucoma drainage devices (GDD). ${ }^{12}$

Trabeculectomy is the most widely performed surgical procedure in refractory glaucomas, but its long-term success rate is limited in UG because of early bleb failure secondary to the accelerated healing response. ${ }^{2}$ The major complication of this procedure is bleb fibrosis. Although the application of antifibrotic agents such as mitomycin $\mathrm{C}$ has been used in surgery, the success rate of filtration surgery remains unsatisfactory. ${ }^{7}$ Landers et al. reported 20-year results of trabeculectomy in different types of glaucomas, and they have found that UG has a significantly lower success rate after trabeculectomy than other types of glaucomas. ${ }^{2}$ Cyclodestructive procedures are irreversible; hence, this treatment option is ofter reversed for eyes with worse visual prognosis. Therefore, GDD is currently considered a better choice in the treatment of uveitic glaucoma. ${ }^{12}$ GDD have been shown to be effective for longterm success in uveitic glaucoma. ${ }^{8}$

GDD creates alternate aqueous pathways by channeling aqueous from the anterior chamber through a long tube to an equatorial plat that promotes bleb formation. ${ }^{14}$ The most commonly used GDD are the valved (Ahmed Glaucoma Valve/AGV) and the non-valved (Molteno and Baerveldt implant). ${ }^{12}$ Molteno and Baerveldt implants offer no resistance to immediate outflow; meanwhile, AGV offers some resistance. ${ }^{14}$

A previous study found the cumulative probability of success AGV implantation of $77-94.4 \%$ at 1 year and $50-80 \%$ at $2-4$ years. There is also a report evaluating Molteno implants in uveitic patients that found survival estimates between $80 \%$ and $95 \%$ at $27-48$ months of follow-up. A small retrospective study of Baerveldt implantation in uveitic eyes found cumulative life-table success rates were $95.8 \%$ at 3 months and $91.7 \%$ at $6-24$ months. ${ }^{15}$

In this study, we evaluate GDD implant outcomes for uveitic glaucoma patients. We recorded data on IOP, VA, eye inflammation, number of glaucoma medication, and number of antiinflammatory medications preoperative and postoperative. Some definitions of success, using numbers such as 21 or 22 $\mathrm{mmHg}$ as the target IOP. According to the data we got, all of them reached the target IOP and required fewer glaucoma medications. GDD implantation appears to be reasonably effective at controlling IOP. Meanwhile, there was no significant improvement for visual acuity, inflammation, and the number of antiinflammatory medications.

Complications of GDD surgery include shallow anterior chamber, hypotony, suprachoroidal hemorrhage, and blockage of the drainage device by blood, fibrin, or iris. Long-term complications include device erosion through the conjunctiva, valve migration, corneal decompensation, drainage device-cornea touch, and retinal detachment. Unlike trabeculectomy, these drainage devices have proven to be robust and continue to function despite chronic, recurrent inflammation, and they provide excellent long-term IOP control in eyes with uveitic glaucoma. ${ }^{1}$ Hypotony is the most frequently reported complication. Uveitic eyes are prone to developing hypotony in the early postoperative period secondary to ciliary body shutdown. ${ }^{16-19}$

This study has several limitations. We do not categorize patients by age, so it is included all uveitic glaucoma patients, pediatric and adults. It has different followup times, range 6 months to 5 years. We do not differentiate the type of GDD. For future research, it needs to standardize the definition of success following a glaucoma surgical procedure. Long term follow-up and prospective evaluation are needed to determine the success of GDD implantation.

\section{CONCLUSION}

Uveitic glaucoma is shown to be managed successfully by GDD implantation. It can be seen from the reduction in IOP in order to preserve vision for patients with uveitic glaucoma, and patients were on fewer glaucoma medications postoperatively. GDD implantation may be considered a long-term effective surgical option for patients with uveitic glaucoma.

\section{CONFLICT OF INTEREST}

The authors state that there is no conflict of interest in this study.

\section{ACKNOWLEDGEMENTS}

None.

\section{FUNDING}

The authors are responsible for the study funding without a grant, scholarship, or any other funding resources. 


\section{AUTHOR CONTRIBUTION}

All authors contributed equally to this study.

\section{REFERENCES}

1. American Academy of Ophthalmology. Uveitis and Ocular Inflammation. San Francisco: American Academy of Ophthalmology. 2019.

2. Sungur G, Yakin M, Eksioglu U, Satana B, Ornek F. Assessment of conditions affecting surgical success of Ahmed glaucoma valve implants in glaucoma secondary to different uveitis etiologies in adults. Eye (Lond). 2017;31(10):1435-1442. doi:10.1038/ eye.2017.84.

3. Chow A, Burkemper B, Varma R, Rodger DC, Rao N, Richter GM. Comparison of surgical outcomes of trabeculectomy, Ahmed shunt, and Baerveldt shunt in uveitic glaucoma. J Ophthalmic Inflamm Infect. 2018;8(1):9. Published 2018 Jun 18. doi:10.1186/s12348018-0150-y.

4. Iverson SM, Bhardwaj N, Shi W, et al. Surgical outcomes of inflammatory glaucoma: a comparison of trabeculectomy and glaucoma-drainage-device implantation. Jpn J Ophthalmol. 2015;59(3):179-186. doi:10.1007/ s10384-015-0372-6.

5. Riordan-Eva P, Witcher JP. Vaughan \& Asbury's General Ophtalmology, 19th Edition. New York: McGraw-Hill Companies. 2018.

6. Watanabe S, Hamanaka T, Sakurai T, Kobayashi $\mathrm{K}$, Ishida $\mathrm{N}$, Ebihara N. Evaluation of the outcome of long-tube shunt implant surgery in uveitic glaucoma patients by analyzing the background of uveitis. Int Ophthalmol. 2021;41(2):509-517. doi:10.1007/s10792-02001601-3.
7. Bao N, Jiang ZX, Coh P, Tao LM. Long-term outcomes of uveitic glaucoma treated with Ahmed valve implant in a series of Chinese patients. Int $J$ Ophthalmol. 2018;11(4):629634. Published 2018 Apr 18. doi:10.18240/ ijo.2018.04.15.

8. Nguyen T, Kim H, Mielke C, Momont AC, Brandt JD, Liu Y. Combined Dexamethasone Intravitreal Implant and Glaucoma Drainage Device Placement for Uveitic Glaucoma. J Glaucoma. 2020;29(4):252-257. doi:10.1097/ IJG.0000000000001454.

9. Bohnsack BL, Freedman SF. Surgical outcomes in childhood uveitic glaucoma. Am J Ophthalmol. 2013;155(1):134-142. doi:10.1016/j.ajo.2012.07.008.

10. Sevgi DD, Davoudi S, Talcott KE, et al. A retrospective study on the outcomes of Ahmed valve versus Ahmed valve combined with fluocinolone implant in uveitic glaucoma. Digit J Ophthalmol. 2017;23(3):63-70. Published 2017 Sep 11. doi:10.5693/djo.01.2017.06.001.

11. Zivney $M$, Lin P, Edmunds B, Parikh $M$, Takusagawa H, Tehrani S. Combined Glaucoma Tube Shunt (Ahmed) and Fluocinolone Acetonide $\quad\left(\right.$ Retisert $\left.^{\mathrm{Tm}}\right)$ Implantation Compared to Ahmed Alone in Uveitic Glaucoma. Ophthalmol Ther. 2016;5(2):223233. doi:10.1007/s40123-016-0066-2.

12. Ramdas WD, Pals J, Rothova A, Wolfs RCW. Efficacy of glaucoma drainage devices in uveitic glaucoma and a meta-analysis of the literature. Graefes Arch Clin Exp Ophthalmol. 2019;257(1):143-151. doi:10.1007/s00417-0184156-9.

13. Bowling B. Kanski's clinical ophthalmology. 8th ed. Sydney: Elsevier; 2016. p. 169-870.

14. Hong $\mathrm{CH}$, Arosemena A, Zurakowski D, Ayyala RS. Glaucoma drainage devices: a systematic literature review and current controversies. Surv
Ophthalmol. 2005;50(1):48-60. doi:10.1016/j. survophthal.2004.10.006.

15. Moore, D.B., Stinnett, S., Jaffe, G.J.et al. Improved Surgical Success of Combined Glaucoma Tube Shunt and Retisert Implantation in Uveitic Eyes: A Retrospective Study.Ophthalmol Ther 4. 2015. p103-113. https://doi.org/10.1007/ s40123-015-0041-3.

16. Eksioglu U, Yakin M, Sungur G, et al. Short- to long-term results of Ahmed glaucoma valve in the management of elevated intraocular pressure in patients with pediatric uveitis. Can J Ophthalmol. 2017;52(3):295-301. doi:10.1016/j. jcjo.2016.11.015.

17. Esfandiari H, Loewen NA, Hassanpour K, et al. Fuchs heterochromic iridocyclitis-associated glaucoma: a retrospective comparison of primary Ahmed glaucoma valve implantation and trabeculectomy with mitomycin C. F1000Res. 2018;7:876. Published 2018 Jun 22. doi:10.12688/f1000research.15244.2.

18. Nilforushan N, Yadgari $M$, Alemzadeh SA. Surgical management of glaucoma in Fuchs uveitis syndrome: Trabeculectomy or Ahmed glaucoma valve. J Curr Ophthalmol. 2018;31(1):24-30. Published 2018 Dec 28. doi:10.1016/j.joco.2018.10.005.

19. Valenzuela F, Oportus MJ, Pérez CI, et al. Ahmed glaucoma drainage implant surgery in the management of refractory uveitic glaucoma: Long-term follow up. Implante de válvula de Ahmed para el manejo del glaucoma uvé́tico refractario: seguimiento a largo plazo. Arch Soc Esp Oftalmol (Engl Ed). 2018;93(9):431-438. doi:10.1016/j.oftal.2018.05.011.

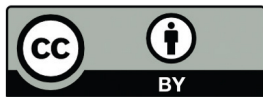

This work is licensed under a Creative Commons Attribution 